\title{
Differential Influence of Inositol Hexaphosphate on the Expression of Genes Encoding TGF- $\beta$ Isoforms and Their Receptors in Intestinal Epithelial Cells Stimulated with Proinflammatory Agents
}

\author{
Małgorzata Kapral, Joanna Wawszczyk, Stanisław Sośnicki, and Ludmiła Węglarz \\ Department of Biochemistry, Medical University of Silesia, Jedności 8, 41-200 Sosnowiec, Poland \\ Correspondence should be addressed to Małgorzata Kapral; mkapral@sum.edu.pl
}

Received 6 August 2013; Revised 8 November 2013; Accepted 27 November 2013

Academic Editor: Dennis Daniel Taub

Copyright (C) 2013 Małgorzata Kapral et al. This is an open access article distributed under the Creative Commons Attribution License, which permits unrestricted use, distribution, and reproduction in any medium, provided the original work is properly cited.

\begin{abstract}
Transforming growth factor $\beta$ (TGF- $\beta$ ) is a multifunctional cytokine recognized as an important regulator of inflammatory responses. The effect of inositol hexaphosphate (IP6), a naturally occurring phytochemical, on the mRNA expression of TGF$\beta 1$, TGF- $\beta 2$, TGF- $\beta 3$ and T $\beta$ RI, T $\beta$ RII, and T $\beta$ RIII receptors stimulated with bacterial lipopolysaccharides (Escherichia coli and Salmonella typhimurium) and IL- $1 \beta$ in intestinal cells Caco- 2 for 3 and $12 \mathrm{~h}$ was investigated. Real-time qRT-PCR was used to validate mRNAs level of examined genes. Bacterial endotoxin promoted differential expression of TGF- $\beta$ s and their receptors in a time-dependent manner. IL-1 $\beta$ upregulated mRNA levels of all TGF- $\beta$ s and receptors at both $3 \mathrm{~h}$ and $12 \mathrm{~h}$. IP 6 elicited the opposed to LPS effect by increasing downregulated transcription of the examined genes and suppressing the expression of TGF- $\beta 1$ at 12 h. IP6 counteracted the stimulatory effect of IL-1 $\beta$ on TGF- $\beta 1$ and receptors expression by decreasing their mRNA levels. IP6 enhanced LPS- and IL-1 $\beta$-stimulated mRNA expression of TGF- $\beta 2$ and - $\beta 3$. Based on these studies it may be concluded that IP6 present in the intestinal milieu may exert immunoregulatory effects and chemopreventive activity on colonic epithelium under inflammatory conditions or during microbe-induced infection/inflammation by modulating the expression of genes encoding TGF- $\beta$ s and their receptors at transcriptional level.
\end{abstract}

\section{Introduction}

Inflammatory bowel disease (IBD) is a chronic inflammation of the gastrointestinal tract thought to be a result of dysregulated or aberrant immune response to intestinal flora and multiple environmental factors with regard to genetic predisposition [1]. Exposure of intestinal epithelial cells (IEC) to bacterial components and products can potentially initiate intestinal inflammation by their release of cytokines chemokines and recruitment of inflammatory cells. IEC can also respond to a broad array of cytokines with altered gene expression and growth characteristics [2]. Cytokine that plays a crucial role in the inflammatory diseases such as IBD is IL$1 \beta$. Enhanced level of this cytokine has been determined in mucosal tissues infected with enteropathogenic bacteria, as well as in mucosal biopsies with active IBD. IL- $1 \beta$ activates intracellular signaling cascades in IEC leading to the increase of expression and secretion of proinflammatory cytokines and chemokines, uncontrolled intestinal inflammation, and disruption of epithelial function $[3,4]$. Lipopolysaccharide (LPS) or endotoxin, the key component of the cell wall of Gram-negative bacteria, stimulates activation of transcription factors and production of proinflammatory cytokines. The expression of LPS specific Toll-like receptor 4 (TLR-4) in human colorectal cancer cells highlighted a key function of TLR system in the development of colitis-associated tumors, suggesting a role of this receptor in colorectal cancer development and progression [2]. Cytokines with 
anti-inflammatory properties have been implicated in the prevention of inappropriate immune activation by intestinal flora.

Transforming growth factor $\beta$ is a strong anti-inflammatory cytokine with multipotent mechanism of action [5]. In mammals three isoforms (TGF- $\beta 1,-\beta 2$, and $-\beta 3$ ) have been described, which share $75 \%$ amino acid sequence homology but are encoded by different genes [6]. TGF$\beta$ s have strong impact on the inflammatory responses and tumor microenvironment including fibroblasts, endothelial cells and immune cells. TGF- $\beta$ s suppress cytotoxic T-cell differentiation and inhibit NK cell and neutrophil effector functions. Also, they have been shown to suppress MHC I and MHC II expression [7]. On the other hand, overexpression of TGF- $\beta$ could induce the secretion of proinflammatory cytokines, for example, TNF- $\alpha$ [8], IL-1 $\beta$, IL-6, and IL-8 [7]. This indicates complexity of TGF- $\beta$ signalling immune regulation within different contexts [9]. TGF- $\beta$ signalling is mediated by three specific types of cell surface proteins: TGF$\beta$ receptor I (T $\beta \mathrm{RI})$, II (T $\beta \mathrm{RII})$, and III (T $\beta \mathrm{RIII}) . \mathrm{T} \beta \mathrm{RIII}$ is a coreceptor modulating intracellular TGF- $\beta$ s activities [10]. TGF- $\beta$ initiates its signaling by binding to T $\beta$ RII, which has intrinsic serine-threonine kinase activity. Then, $\mathrm{T} \beta \mathrm{RII}$ recruits and phosphorylates $\mathrm{T} \beta \mathrm{RI}$, establishing heterotetrameric complex consisting of two T $\beta$ RII and two T $\beta$ RI [11]. T $\beta$ RI initiates phosphorylation of the adaptor proteins SMAD2 and SMAD3 which is followed by the formation of complex with SMAD4 [5]. Nuclear SMAD complexes bind to SMAD-binding elements on DNA, affecting transcriptional activity which is dependent on their interaction with coactivators [12]. SMAD7 differs structurally from other members of SMAD family and functions as a negative regulator of TGF- $\beta$ signaling. Its gene expression is induced by TGF- $\beta$; thus SMAD7 represents negative feedback loop, restraining TGF- $\beta$ activity [13]. It recruits the GADD34 complex to the T $\beta$ RI, thus preventing SMAD2/SMAD3 phosphorylation and TGF- $\beta$ signal transduction. SMAD7 also contributes to $\mathrm{T} \beta \mathrm{RI}$ dephosphorylation and ubiquitination and proteasomal degradation of the TGF- $\beta$ receptor complex [14]. Many factors modulate the TGF- $\beta$-mediated cellular response. Transcription factors, histone readers, modifiers, and chromatin remodelers that bind to activated SMAD determine what genes and how they will be affected by signal transduction complexes. TGF- $\beta$ can also activate other nonSMAD signalling pathways, including PI3K, MAPK, TRAF6, and mTORC [15]. Some of the important downstream targets of TGF- $\beta$ signaling include cell cycle checkpoint genes, the activation of which leads to growth arrest. Yet, TGF- $\beta$ signaling can also directly stimulate the production of several mitogenic growth factors which can drive the carcinogenic process [16]. A number of inflammatory diseases including inflammatory bowel disease and cancer are associated with abnormal TGF- $\beta$ s regulation $[5,17,18]$. Monteleone et al. [19] have shown marked overexpression of SMAD7 in the inflamed tissue of IBD patients. Moreover it was associated with a reduction in SMAD3 phosphorylation, which is crucial for anti-inflammatory action of TGF- $\beta$. Proinflammatory stimuli, such as TNF- $\alpha$, IL- $1 \beta$, and INF- $\gamma$, also induce SMAD7 expression [20]. Chronic inflammation has been recognized to be associated with a high cancer risk and may be involved in all stages of tumor development, that is, initiation, promotion, and progression [21]. The control of colitis by certain anti-inflammatory agents reduced colon cancer incidence [22].

Colorectal cancer is one of the most common cancers, accounting for $8 \%$ of all cancer deaths, making it the fourth cause of cancer deaths[23]. Due to high mortality and extensive anticancer drugs toxicity there has been growing interest in substances that may have chemopreventive action, that is, can prevent or delay the development of cancer [24, 25]. Diet has been proved to play a significant role in the aetiology of colorectal cancer. Consumption of dietary components with anti-inflammatory activity has been associated with reduced risk of developing colorectal cancer. One of the essential components of high fiber diet is inositol hexaphosphate (IP6) [26]. It is a naturally occurring hexaphosphorylated carbohydrate, found in both plant and mammalian cells [27]. With intracellular concentration of about $100 \mu \mathrm{M}$, IP6 participates in a variety of cellular functions such as signal transduction, regulation of cell proliferation, and differentiation [28]. IP6 has been shown in in vitro studies to inhibit growth of human breast, colon, prostate, and liver cancer cells. Its anticancer properties have been documented to result from its antiproliferative, proapoptotic, and antiangiogenic effects. IP6 is also known for its antioxidant properties, prevention against formation of kidney stones, high blood cholesterol level and heart and liver diseases [27]. Its antioxidant action was recognized in experimental models of myocardial reperfusion injury, pulmonary inflammation, and peptic ulcer induction [28]. Therefore, IP6 is believed to have potential to serve as preventive agent for chronic inflammation and carcinogenesis [29]. Recently, it has been revealed that IP6 has strong impact on transcriptional activity of TGF- $\beta$ s and their receptor genes in colon cancer cells [30].

The aim of the present study was to examine the potential of IP6 to affect proinflammatory agents-influenced changes in transcriptional activity of the genes encoding TGF- $\beta 1$, TGF- $\beta 2$, and TGF- $\beta 3$ and their receptors T $\beta$ RI, T $\beta$ RII, and $\mathrm{T} \beta \mathrm{RIII}$ in human colon Caco- 2 cells.

\section{Materials and Methods}

2.1. Cell Culture and Cell Stimulation Assays. The Caco-2 human intestinal epithelial cells (DSMZ, Braunschweig, Germany) were routinely cultured in RPMI 1640 medium (Sigma Aldrich) supplemented with $10 \%$ fetal bovine serum (GibcoBRL), $100 \mathrm{U} / \mathrm{mL}$ penicillin and $100 \mu \mathrm{g} / \mathrm{mL}$ streptomycin (both from Sigma Aldrich) and $10 \mathrm{mM}$ HEPES (GibcoBRL). They were maintained at $37^{\circ} \mathrm{C}$ in a $5 \% \mathrm{CO}_{2}$ atmosphere within a humidified incubator. Cells were seeded into six-well plates (Nunc International) at a density of $4.5 \times 10^{5}$ per well and allowed to grow to $80 \%$ confluency in $3 \mathrm{~mL}$ of medium. After three days the culture media were changed to media with $2 \%$ FBS and cells were then cultured for 2 days. They were then stimulated with $100 \mu \mathrm{g} / \mathrm{mL}$ LPS (Escherichia coli serotype 055:B5, Salmonella enterica serotype typhimurium; 
both from Sigma Aldrich), or $1 \mathrm{ng} / \mathrm{mL}$ IL-1 $\beta$ (Sigma Aldrich) for $30 \mathrm{~min}$. Afterwards cells were treated with $2.5 \mathrm{mM}$ IP6 as dipotassium salt (distilled water dissolved and $\mathrm{pH} 7.4$ adjusted) (Sigma Aldrich) for 3 and $12 \mathrm{~h}$. In separate cultures, cells were incubated with LPS or IL- $1 \beta$ at the indicated concentrations and for the indicated times. The untreated Caco- 2 cells were used as the control.

2.2. RNA Extraction. Total RNA was extracted from cells using TRIzol reagent (Invitrogen) according to the manufacturer's specifications. Integrity of the RNA extracts was qualitatively checked by electrophoresis in 1.0\% agarose gel stained with ethidium bromide. RNA concentration was determined spectrophotometrically on the basis of absorbance values at a wavelength of $260 \mathrm{~nm}$ using a GeneQuant pro (Amersham Biosciences).

2.3. Real-Time $q R T-P C R$ Assay. Detection of the expression of genes encoding TGF- $\beta$ isoforms and their receptors was carried out using a qRT-PCR technique with a SYBR Green chemistry (SYBR Green Quantitect RT-PCR Kit, Qiagen) and Opticon DNA Engine Continuous Fluorescence detector (MJ Research) as described previously [31]. Oligonucleotide primers specific for TGF- $\beta 1$, TGF- $\beta 2$, TGF- $\beta 3$, T $\beta$ RI, T $\beta$ RII, and T $\beta$ RIII mRNAs were designed using Primer Express 2.0 software (PE Applied Biosystems, USA) (Table 1). The thermal profile for one-step RT-PCR was as follows: $50^{\circ} \mathrm{C}$ for $30 \mathrm{~min}$ for reverse transcription and $95^{\circ} \mathrm{C}$ for $15 \mathrm{~min}$ followed by 45 cycles at $94^{\circ} \mathrm{C}$ for $15 \mathrm{~s}, 55^{\circ} \mathrm{C}$ for $30 \mathrm{~s}$, and $72^{\circ} \mathrm{C}$ for $45 \mathrm{~s}$ for amplification. Following RT-PCR, the samples were subjected to temperature ramp from $60^{\circ} \mathrm{C}$ to $95^{\circ} \mathrm{C}$ at the rate of $0.2^{\circ} \mathrm{C} / \mathrm{s}$ with continuous fluorescence monitoring for melting curve analysis. Each gene analysis was performed in triplicate. A commercially available standard of $\beta$-actin (TaqMan DNA Template Reagent Kit, Applied Biosystems) was used to estimate the mRNA copy numbers of examined genes. The obtained results of mRNA copy number were recalculated per $\mu \mathrm{g}$ of total RNA. The expression level of examined genes in cultured cells was expressed as the fold change relative to the control. The value of fold change $>1$ reflects increased expression of the target gene, and a value of fold change $<1$ points to a decrease in the gene expression. Finally, specificity of RT-PCR reaction was confirmed by determining the characteristic temperature of melting for each amplimer and by 6\% polyacrylamide gel (PAA) electrophoresis of RT-PCR products with their visualization using silver staining.

2.4. Statistical Analysis. The results were collected based on three independent experiments. Statistical analysis was performed with the use of Statistica PL 9.0 software. All the results are expressed as means \pm SD. Comparison of two data sets was performed by unpaired $t$-test. Significance level was assumed for $P<0.05$.

\section{Results}

The colon cancer cells Caco-2 showed constitutive expression of genes encoding all three TGF- $\beta$ isoforms and their receptors.

3.1. Changes of TGF- $\beta 1$ Expression by the Effect of Proinflammatory Agents and IP6. In the time course of the experiment, differential TGF- $\beta 1$ expression after exposure of Caco- 2 to $E$. coli LPS was observed. At $3 \mathrm{~h}$, it decreased in comparison to control $(P=0.025)$ and IP6 up regulated LPS-evoked effect $(P=0.032)$. A significantly higher TGF- $\beta 1 \mathrm{mRNA}$ level was determined following cell treatment with LPS for $12 \mathrm{~h}$ than in unstimulated cells $(P=0.047)$. LPS-stimulated transcription of this gene was remarkably down-regulated by IP6 at that time $(P=0.01)$ (Figures $1(\mathrm{a})$ and $1(\mathrm{~b}))$. Endotoxin of $S$. typhimurium had no influence on TGF- $\beta 1$ mRNA level after $3 \mathrm{~h}$ treatment $(P=0.487)$ but longer exposure of cells to it $(12 \mathrm{~h})$ caused significant decrease in transcription of the gene $(P<0.001)$ (Figure 1(a)). The levels of TGF- $\beta 1$ mRNA in cells stimulated with $S$. Typhi. LPS and cells treated with both LPS and IP6 revealed no statistically significant differences after 3 and $12 \mathrm{~h}(P>0.05)$ (Figure 1(b)). Incubation of Caco-2 with IL- $1 \beta$ for both 3 and $12 \mathrm{~h}$ up-regulated TGF- $\beta 1$ gene as compared with untreated cells $(P<0.05)$ (Figure 1(a)). After $3 \mathrm{~h}, 2.5 \mathrm{mM}$ IP6 did not change TGF- $\beta 1$ expression stimulated by IL-1 $\beta(P=0.268)$. Furthermore, significant decrease in the expression of this gene was revealed in cells exposed to IL- $1 \beta$ and IP6 for $12 \mathrm{~h}(P=0.047)$ in comparison to the cultures treated with IL-1 $\beta$ only (Figure 1(b)).

3.2. Changes of TGF- $\beta 2$ Expression by the Effect of Proinflammatory Agents and IP6. LPS of E. coli gradually downregulated TGF- $\beta 2$ expression within $3-12 \mathrm{~h}(P<0.05)$ (Figure 2(a)) and IP6 was able to enhance it markedly at both time points in comparison to LPS effects only $(P<$ 0.05) (Figure 2(b)). In response to LPS of Salmonella Caco-2 exhibited significantly higher transcription of this gene than control after $3 \mathrm{~h}(P=0.001)$. However, the prolongation of time to $12 \mathrm{~h}$ led to insignificantly reduced TGF- $\beta 2$ expression $(P=0.130)$ (Figure 2(a)). IP6 enhanced LPS-stimulated transcription of this gene after $3 \mathrm{~h}(P<0.001)$. Subsequently $(12 \mathrm{~h})$, the combination of IP6 and LPS gave rise to 2 -fold increase in TGF- $\beta 2$ mRNA level $(P=0.002)$ compared to LPS-treated cells (Figure 2(b)). The TGF- $\beta 2$ transcript was over 2 -fold higher by the treatment with IL- $1 \beta$ for $3 \mathrm{~h}$ $(P=0.007)$ and $12 \mathrm{~h}(P=0.001)$ as compared to control (Figure 2(a)). When IP6 was added to IL-1 $\beta$-prestimulated cultures, the level of TGF- $\beta 2$ mRNA markedly raised at $3 \mathrm{~h}$ in comparison to those treated with IL-1 $\beta$ alone $(P<0.0001)$ (Figure 2(b)).

3.3. Changes of TGF- $\beta 3$ Expression by the Effect of Proinflammatory Agents and IP6. E. coli LPS diminished transcriptional activity of TGF- $\beta 3$ gene in Caco- 2 cells in a timedependent manner. The decrease of the TGF- $\beta 3$ mRNA level was statistically significant compared to control at $12 \mathrm{~h}(P<$ 0.0001) (Figure 3(a)). IP6 enhanced the expression of this 
TABLE 1: Characteristics of primers used in experiment.

\begin{tabular}{|c|c|c|c|}
\hline Gene & Primer sequence & Product amplified (bp) & $\mathrm{TM}\left({ }^{\circ} \mathrm{C}\right)$ \\
\hline \multirow{2}{*}{ TGF- $\beta 1$} & F: 5'-TGAACCGGCCTTTCCTGCTTCTCATG-3' & \multirow{2}{*}{151} & \multirow{2}{*}{85} \\
\hline & R: 5'-GCGGAAGTCAATGTACAGCTGCCGC-3' & & \\
\hline \multirow{2}{*}{ TGF- $\beta 2$} & F: 5'-TACTACGCCAAGGAGGTTTACAAA-3' & \multirow{2}{*}{201} & \multirow{2}{*}{80} \\
\hline & R: 5'-TTGTTCAGGCACTCTGGCTTT-3' & & \\
\hline \multirow{2}{*}{ TGF- $\beta 3$} & F: 5'-CTGGATTGTGGTTCCATGCA-3' & \multirow{2}{*}{121} & \multirow{2}{*}{81} \\
\hline & R: 5'-TCCCCGAATGCCTCACAT-3' & & \\
\hline \multirow{2}{*}{$\mathrm{T} \beta \mathrm{RI}$} & F: 5'-ACTGGCAGCTGTCATTGCTGGACCAG-3' & \multirow{2}{*}{201} & \multirow{2}{*}{81} \\
\hline & R: 5'-CTGAGCCAGAACCTGACGTTGTCATATCA-3' & & \\
\hline \multirow{2}{*}{$\mathrm{T} \beta \mathrm{RII}$} & F: 5'-GGCTCAACCACCAGGGCATCCAGAT-3’ & \multirow{2}{*}{139} & \multirow{2}{*}{84} \\
\hline & R: $5^{\prime}$-CTCCCCGAGAGCCTGTCCAGATGCT-3' & & \\
\hline \multirow{2}{*}{$\mathrm{T} \beta$ RIII } & F: 5'-ACCGTGATGGGCATTGCGTTTGCA-3' & \multirow{2}{*}{173} & \multirow{2}{*}{85} \\
\hline & R: 5'-GTGCTCTGCGTGCTGCCGATGCTGT-3' & & \\
\hline
\end{tabular}

bp: base pair; TM: temperature of melting.

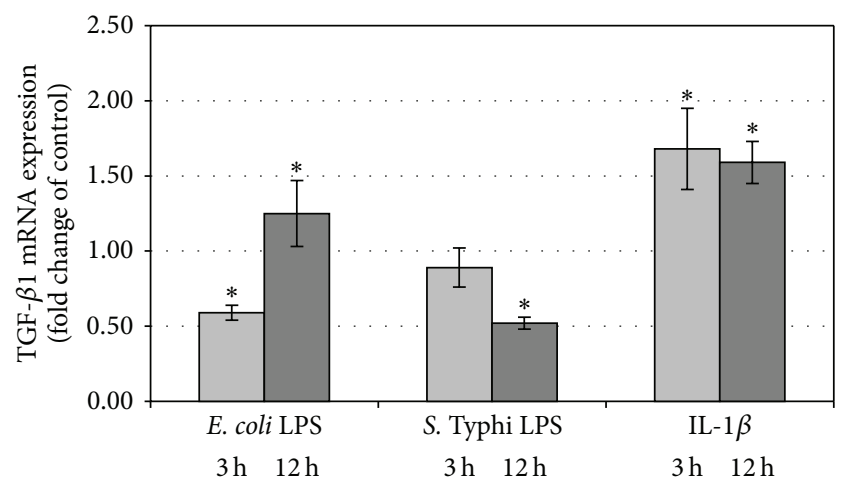

(a)

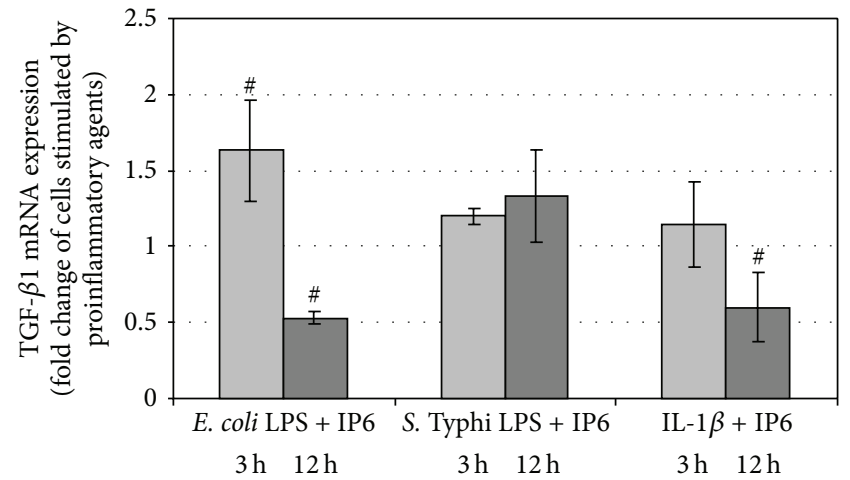

(b)

FIGURE 1: Expression of TGF- $\beta 1$ gene in Caco- 2 cells as determined by real-time RT-PCR. Changes in TGF- $\beta 1$ mRNA expression in Caco2 cells after treatment with (a) proinflammatory agents and (b) proinflammatory agents and $2.5 \mathrm{mM}$ IP6 for $3 \mathrm{~h}$ and $12 \mathrm{~h}$. The results are presented as mean \pm SD of three separate experiments; ${ }^{*} P<0.05$ versus control Caco- 2 cells; ${ }^{\#} P<0.05$ versus proinflammatory agentsstimulated cells.

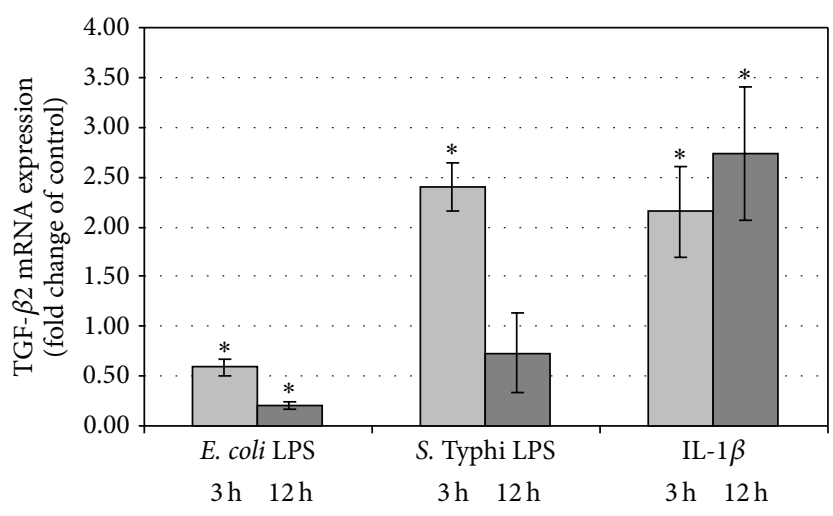

(a)

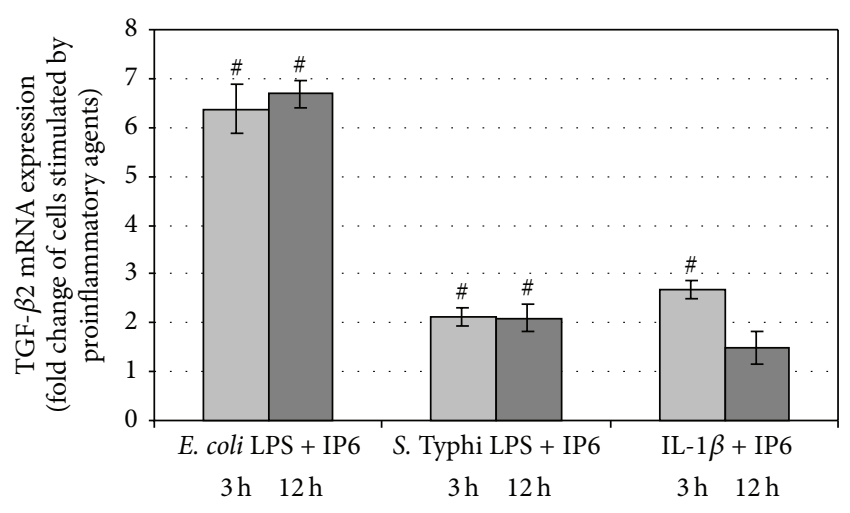

(b)

FIGURE 2: Expression of TGF- $\beta 2$ gene in Caco- 2 cells as determined by real-time RT-PCR. Changes in TGF- $\beta 2$ mRNA expression in Caco2 cells after treatment with (a) proinflammatory agents and (b) proinflammatory agents and $2.5 \mathrm{mM}$ IP6 for $3 \mathrm{~h}$ and $12 \mathrm{~h}$. The results are presented as mean \pm SD of three separate experiments; ${ }^{*} P<0.05$ versus Caco- 2 cells; ${ }^{\#} P<0.05$ versus proinflammatory agents-stimulated cells. 


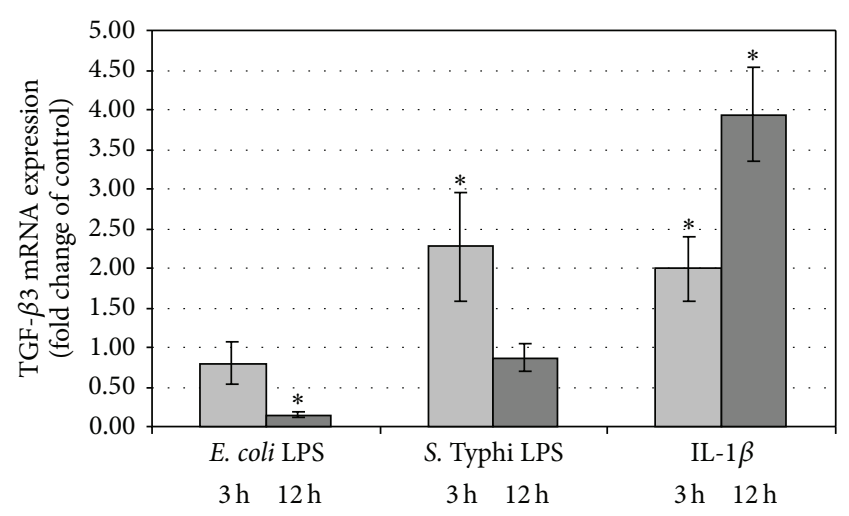

(a)

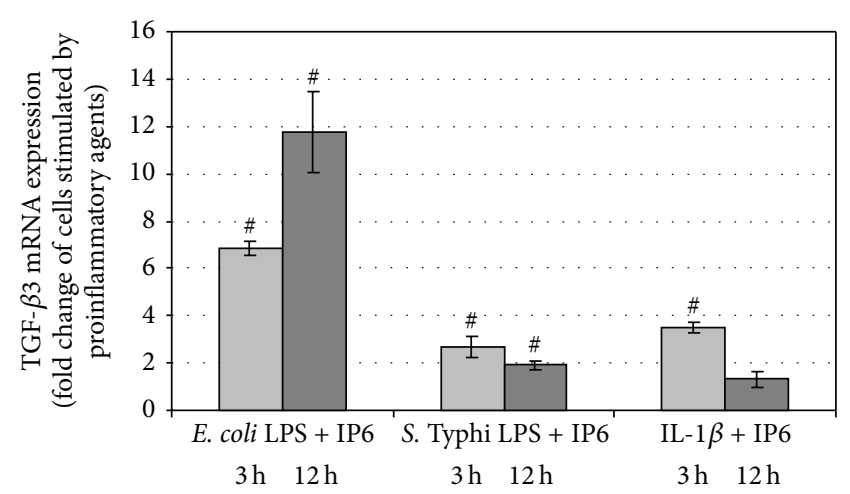

(b)

FIGURE 3: Expression of TGF- $\beta 3$ gene in Caco- 2 cells as determined by real-time RT-PCR. Changes in TGF- $\beta 3$ mRNA expression in Caco2 cells after treatment with (a) proinflammatory agents and (b) proinflammatory agents and $2.5 \mathrm{mM}$ IP6 for $3 \mathrm{~h}$ and $12 \mathrm{~h}$. The results are presented as mean $\pm \mathrm{SD}$ of three separate experiments; ${ }^{*} P<0.05$ versus control Caco- 2 cells; ${ }^{\#} P<0.05$ versus proinflammatory agentsstimulated cells.

gene after $3 \mathrm{~h}(P<0.0001)$ and $12 \mathrm{~h}(P<0.0001)$ with reference to LPS-stimulated cells (Figure 3(b)). Cell cultures treated with LPS of $S$. Typhi manifested above 2 -fold increase in TGF- $\beta 3$ mRNA expression compared to control culture at $3 \mathrm{~h}(P=0.016)$ and IP6 markedly enhanced LPS-induced expression of this isoform $(P=0.008)$. Incubation of cells with $S$. Typhi LPS for $12 \mathrm{~h}$ did not change mRNA level of TGF$\beta 3$ compared to control $(P=0.286)$. In cells exposed to LPS and IP6 statistically significant increase in mRNA for TGF$\beta 3$ in relation to cells treated with $S$. Typhi LPS only ( $P=$ 0.005 ) was observed (Figures $3(a)$ and $3(b))$. IL-1 $\beta$ induced transcriptional activity of this gene by 2 -fold after $3 \mathrm{~h}(P=$ $0.009)$ and about 4 -fold after $12 \mathrm{~h}(P<0.0001)$ as compared to unstimulated cells (Figure 3(a)). IP6 modified IL-1 $\beta$ effects by significant increasing of TGF- $\beta 3$ mRNA expression at $3 \mathrm{~h}$ $(P<0.001)$ (Figure 3(b)).

3.4. The Effect of IP6 on TRRI Expression in Caco-2 Cells Stimulated by Bacterial Endotoxins and IL-1 $\beta$. Lipopolysaccharide of E. coli downregulated transcriptional activity of the gene encoding type I TGF- $\beta$ receptor in Caco- 2 at $3 \mathrm{~h}$ $(P<0.001)$ (Figure 4(a)) while IP6 strongly induced it $(P<0.0001)$ (Figure 4(b)). At $12 \mathrm{~h}$, the expression of the gene in control and LPS-stimulated cultures was comparable $(P=0.075)$, and there were no changes in T $\beta$ RI mRNA amount in the cells treated with LPS and IP6 $(P=0.479)$ (Figures 4(a) and 4(b)). Caco-2 exposed to LPS of Salmonella Typhi for $3 \mathrm{~h}$ produced significantly higher quantity of T $\beta$ RI transcript than control $(P<0.001)$. The amount of T $\beta$ RI mRNA in cells treated with LPS/IP6 and LPS-stimulated cells was similar $(P>0.05)$. Treatment of Caco-2 cells with Salmonella Typhi LPS for $12 \mathrm{~h}$ resulted in statistically significant decrease in T $\beta$ RI gene transcription $(P=0.016)$ which was remarkably up-regulated by IP6 $(P<0.004)$ (Figures 4(a) and 4(b)). By comparison, IL$1 \beta$ induced transcriptional activity of T $\beta$ RI gene in Caco2 cells. The extent of stimulation by this cytokine was 3.9and 2.6-fold after $3 \mathrm{~h}$ and $12 \mathrm{~h}$, respectively, compared to the control $(P<0.05)$ (Figure 4(a)). Nevertheless, $2.5 \mathrm{mM}$ IP6 did not significantly change mRNA T $\beta$ RI expression in IL- $1 \beta$ treated cultures throughout the time period of the experiment $(P>0.05)$ (Figure 4(b)).

3.5. The Effect of IP6 on T $\beta R I I$ Expression in Caco-2 Cells Stimulated by Bacterial Endotoxins and IL-1 $\beta$. Over the period of the experiment, a statistically significant decrease in the expression of T $\beta$ RII in cultures treated with LPS of E. coli in relation to control $(P<0.05)$ was detected. By comparison, IP6 stimulated LPS-decreased transcription of T $\beta$ RII for both $3 \mathrm{~h}(P=0.017)$ and $12 \mathrm{~h}(P=0.003)$ (Figures $5(\mathrm{a})$ and $5(\mathrm{~b}))$. The transcription of T $\beta$ RII did not differ in the control cells and the cells stimulated with LPS of Salmonella for $3 \mathrm{~h}(P=0.129)$. Moreover, cultures treated with LPS and LPS/IP6 revealed similar level of T $\beta$ RII transcript at this time point $(P=0.468)$. Cell culturing with Salmonella tyhpi LPS for $12 \mathrm{~h}$ decreased T $\beta$ RII mRNA level as compared to the control $(P<0.001)$. Transcriptional activity of this gene was upregulated in response to $2.5 \mathrm{mM}$ IP6 $(P=0.001)$ (Figures $5(\mathrm{a})$ and $5(\mathrm{~b}))$. Exposure of Caco-2 to IL- $1 \beta$ for both $3 \mathrm{~h}$ and $12 \mathrm{~h}$ resulted in above 3 -fold up-regulation of T $\beta$ RII gene as compared with untreated cells $(P<0.05)$. At $3 \mathrm{~h}$, T $\beta$ RII gene was found to be expressed at the same level in IL-1 $\beta$ stimulated cells and cells treated with both IL-1 $\beta$ and IP6 $(P=$ 0.312 ). In longer-lasting cultures, transcriptional activity of this gene was significantly suppressed by IP6 in cells treated with IL-1 $\beta /$ IP6 in comparison to those challenged with IL-1 $\beta$ alone $(P=0.023)$ (Figures 5(a) and 5(b)).

3.6. The Effect of IP6 on TßRIII Expression in Caco-2 Cells Stimulated by Bacterial Endotoxins and IL-1 $\beta$. In $3 \mathrm{~h}$ and $12 \mathrm{~h}$ lasting cultures, the expression of T $\beta$ RIII was significantly lowered by LPS of $E$. coli compared to control cells $(P<$ 0.05) (Figure 6(a)). LPS-treated cells exposed to IP6 presented an increase in transcriptional activity of the gene in comparison to cells incubated with LPS only $(P<0.001)$. The considerable, that is, 3.5-fold and 2.6-fold enhancement 


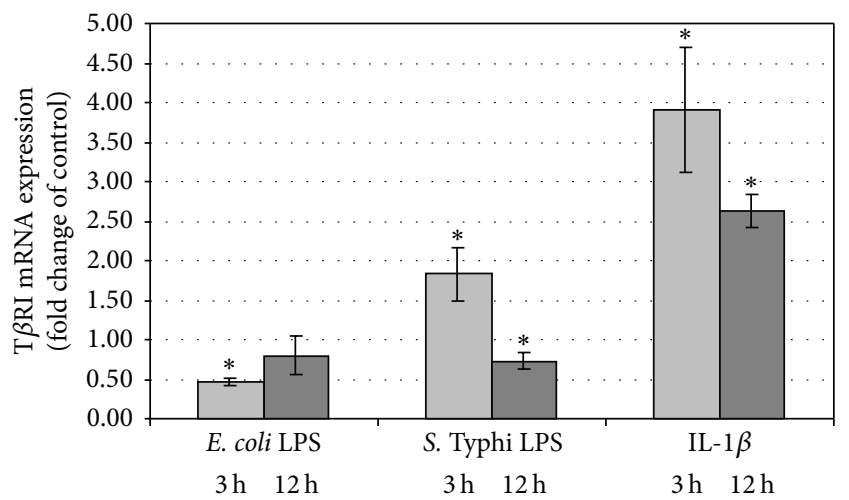

(a)

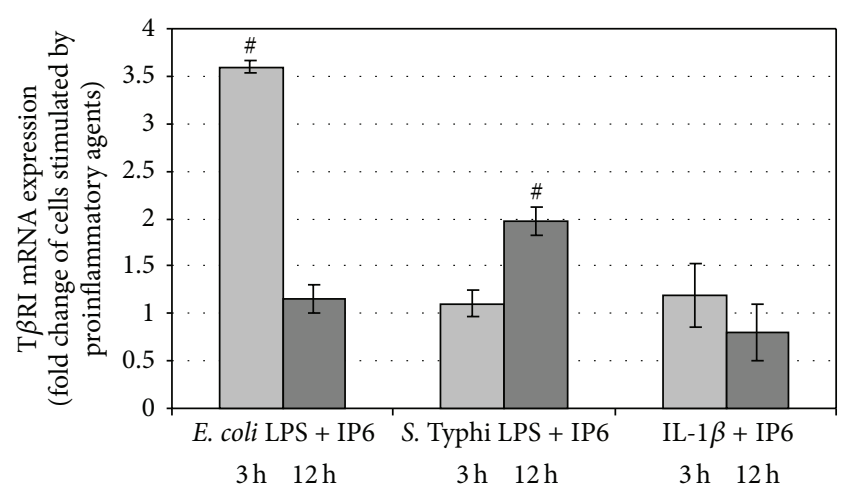

(b)

FIGURE 4: Expression of T $\beta$ RI gene in Caco- 2 cells as determined by real-time RT-PCR. Changes in T $\beta$ RI mRNA expression in Caco- 2 cells after treatment with (a) proinflammatory agents and (b) proinflammatory agents and $2.5 \mathrm{mM}$ IP6 for $3 \mathrm{~h}$ and $12 \mathrm{~h}$. The results are presented as mean \pm SD of three separate experiments; ${ }^{*} P<0.05$ versus control Caco- 2 cells; ${ }^{\#} P<0.05$ versus proinflammatory agents-stimulated cells.

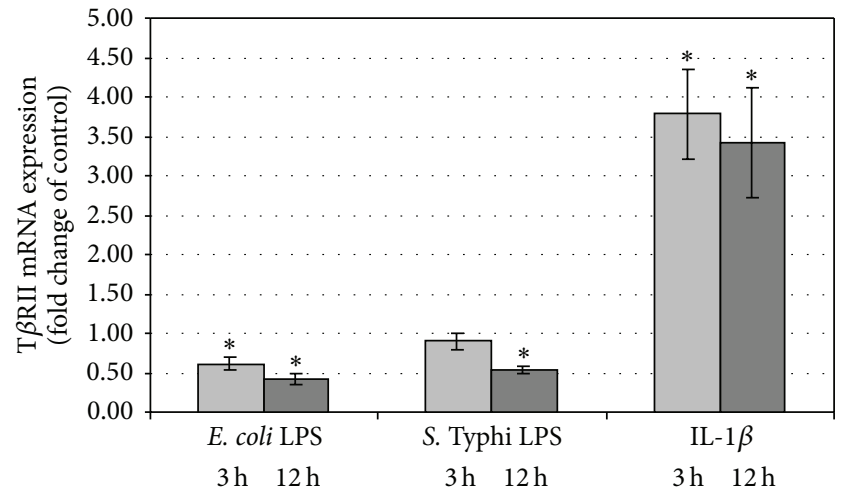

(a)

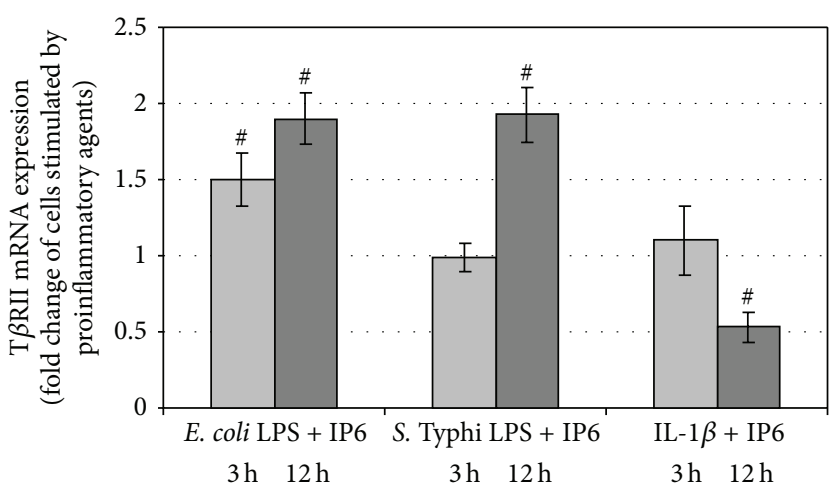

(b)

FIGURE 5: Expression of T $\beta$ RII gene in Caco- 2 cells as determined by real-time RT-PCR. Changes in T $\beta$ RII mRNA expression in Caco-2 cells after treatment with (a) proinflammatory agents and (b) proinflammatory agents and $2.5 \mathrm{mM}$ IP6 for $3 \mathrm{~h}$ and $12 \mathrm{~h}$. The results are presented as mean $\pm \mathrm{SD}$ of three separate experiments; ${ }^{*} P<0.05$ versus control Caco- 2 cells; ${ }^{\#} P<0.05$ versus proinflammatory agents-stimulated cells.

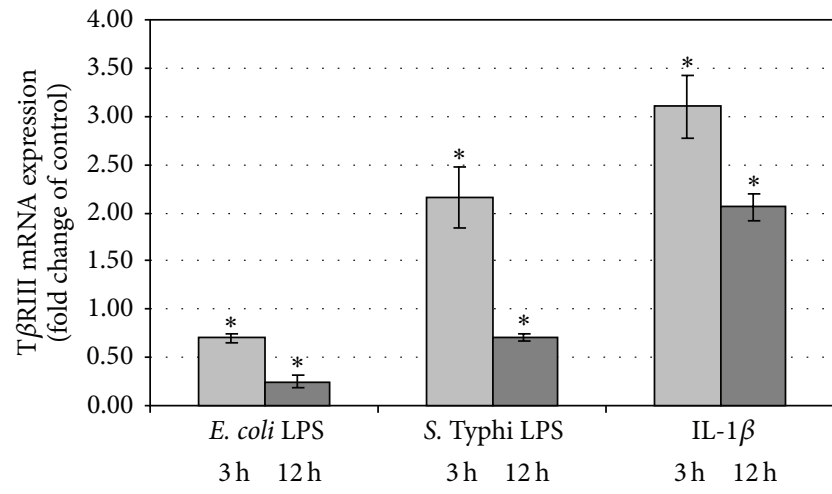

(a)

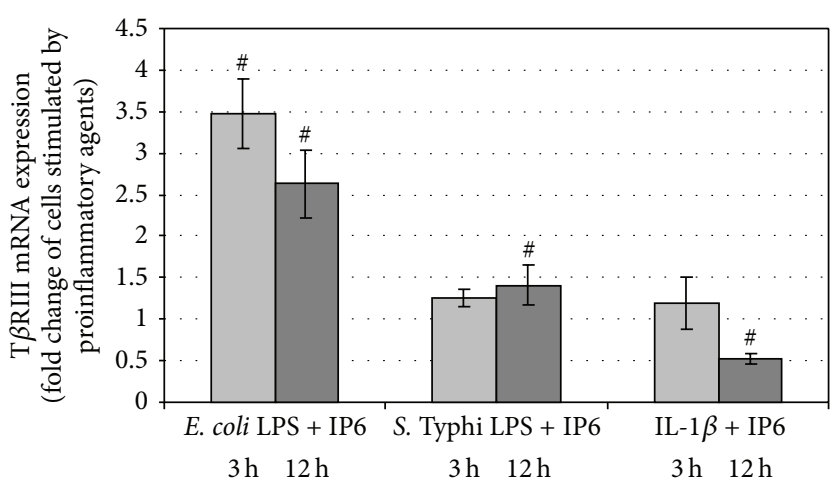

(b)

FIGURE 6: Expression of T $\beta$ RIII gene in Caco- 2 cells as determined by real-time RT-PCR. Changes in T $\beta$ RIII mRNA expression in Caco-2 cells after treatment with (a) proinflammatory agents and (b) proinflammatory agents and $2.5 \mathrm{mM}$ IP6 for $3 \mathrm{~h}$ and $12 \mathrm{~h}$. The results are presented as mean $\pm \mathrm{SD}$ of three separate experiments; ${ }^{*} P<0.05$ versus control Caco- 2 cells; ${ }^{\#} P<0.05$ versus proinflammatory agents-stimulated cells. 
of T $\beta$ RIII mRNA expression was observed after $3 \mathrm{~h}$ and $12 \mathrm{~h}$, respectively, $(P<0.05)$ (Figures 6(a) and 6(b)). Cells exposed to LPS of $S$. Typhi for $3 \mathrm{~h}$ produced significantly higher quantity of T $\beta$ RIII transcript $(P<0.001)$ which has not been changed by IP6 $(P>0.05)$. Furthermore, after $12 \mathrm{~h}$, endotoxin of $S$. Typhi reduced transcription of the gene encoding type III receptor $(P=0.043)$, which was markedly up-regulated by IP6 $(P=0.041)$. Treatment of cells with IL$1 \beta$ for both $3 \mathrm{~h}$ and $12 \mathrm{~h}$ showed a significant $(P<0.0001)$ increase in the expression of T $\beta$ RIII in comparison with control. However, no statistically significant change in its mRNA level in cultures with IL- $\beta$ /IP6 and IL-1 $\beta$ only was detected after $3 \mathrm{~h}(P=0.130)$. After $12 \mathrm{~h}$, a marked decrease in IL- $1 \beta$-enhanced T $\beta$ RIII transcript level was observed in response to IP6 $(P<0.001)$ (Figures 6(a) and 6(b)).

\section{Discussion and Conclusions}

The researches over the past few years have shown unique and essential roles for TGF- $\beta$ in regulating inflammatory and adaptive immune responses. In particular, TGF- $\beta$ antagonizes the activation of the key proinflammatory cytokines including IL- $1 \beta$ and TNF- $\alpha[13,32]$.

The anti-inflammatory treatment strategies can rely on inhibition of proinflammatory cytokine production, receptor binding, signaling, or induction/up-regulation of antiinflammatory and immunoregulatory cytokines [2]. Various synthetic and natural compounds showing anti-inflammatory properties have been identified. Studies conducted in vitro and in vivo have demonstrated that phytochemicals, such as curcumin, resveratrol, and genistein, exert chemopreventive effect by targeting the constituents of inflammatory signal pathways $[32,33]$.

IP6, a natural phytochemical, has recently been described as having immunoregulatory properties. The studies of Cherng et al. [34] showed that IP6 significantly suppressed the secretion of IL-10 and augmented IFN- $\gamma$ production in human peripheral blood mononuclear cells. This compound can modulate the inflammatory response of IEC by regulating their expression and secretion of cytokines and chemokines. Our previous studies revealed that IP6 down-regulated both the IL- $1 \beta$-stimulated increase of IL- 8 release from enterocytes and the cellular response to bacterial LPS [35]. Moreover, it appeared to influence the expression of TNF- $\alpha$, proinflammatory cytokine, and its receptors TNFRI and TNFRII in colon cancer cells [36]. IP6 could also inhibit IL-1 $\beta$-stimulated expression of IL- 6 and IL- 8 at the transcriptional level in IEC [37].

In the present study, we evaluated the influence of IP6 on the expression of TGF- $\beta 1,-\beta 2$, and $-\beta 3$ and their receptors $\mathrm{T} \beta \mathrm{RI}, \mathrm{T} \beta \mathrm{RII}$, and $\mathrm{T} \beta \mathrm{RIII}$ in human intestinal cells under inflammatory conditions. The intestinal epithelium plays important roles in maintaining immune homeostasis in the gut and participates in maintenance of tolerance toward the microflora and food antigens [38]. The cells of intestinal epithelium are capable of producing and releasing IL- $1 \beta$, IL-6, TNF- $\alpha$, and TGF- $\beta$, either spontaneously or during the course of intestinal mucosa inflammation [35, 38-40]. Therefore, we used LPS derived from E. coli and S. Typhi, as well as IL-1 $\beta$ as a relevant in vitro model, to study the regulation of TGF- $\beta$ isoforms and their receptors expression in colon epithelial cells. The cell line Caco-2 (enterocyte-like) utilized in the present experiment is a well-established and widely used model of human intestinal barrier [41].

Lipopolysaccharide released from Gram-negative bacteria cell surface is one of the most potent innate immuneactivating stimuli known [42]. Over the last years, the effects of enteropathogenic and enteroinvasive bacteria and members of the normal intestinal microflora on the expression of TGF- $\beta$ s were examined. However, these studies revealed that commensal and pathogenic species induced fundamentally different cytokine responses in human intestinal epithelial cell lines [43]. The results of Zeuthen et al. [38] showed that the presence and composition of enteric bacteria affects the production of IEC-derived TGF- $\beta$ and that the modulatory effect of this cytokine is highly dependent on the bacterial stimulus. The authors indicated relatively high production of TGF- $\beta 1$ in nonstimulated Caco- 2 cells and its further increase by stimulation with both G-positive and G-negative commensals [38]. The results of Yoshioka et al. [40] studies demonstrated that intestinal epithelial DLD1 cells increased TGF- $\beta 1$ and LoVo cells increased TGF- $\beta 2$ secretion, at $12 \mathrm{~h}$ in response to $E$. coli LPS. However, no significant changes in TGF- $\beta$ s production in hepatocellular carcinoma and myelomonocytic cell lines were observed following stimulation with LPS. Considerable upexpression of mRNAs for TGF- $\beta 1$, TGF- $\beta 2$, and TGF- $\beta 3$ was detected in human intestinal line HT-29 after $3 \mathrm{~h}$ coculture with enterotoxigenic E. coli. Furthermore, the infection the cells with both enteropathogenic E. coli and S. typhimurium led to the high induction of TGF- $\beta 3$ mRNA only. There were insignificant differences in TGF- $\beta 1$ and TGF- $\beta 2$ mRNAs in control and cells exposed to both pathogens. Additionally, the authors indicated significantly reduced expression of all TGF$\beta$ isoforms in HT-29 incubated with commensal bacteria. The majority of bacteria also reduced TGF- $\beta 1$ expression in Caco2 cell line. Also, a significant increase in TGF- $\beta 2$ and decrease in TGF- $\beta 3$ mRNAs in these cells co-cultured with commensal E. coli were determined [43].

In our study, LPS derived from $E$. coli down-regulated mRNA levels of TGF- $\beta 2$ and TGF- $\beta 3$ and all types of receptors in Caco- 2 cells over the course of the experiment. In the case of TGF- $\beta 1$, its reduced transcriptional activity was seen after $3 \mathrm{~h}$ of incubation. However, a longer stimulation of cells with LPS caused up-expression of this isoform. IP6 elicited the opposed to E. coli LPS effect by increasing downregulated transcription of the examined genes and by suppressing the expression of TGF- $\beta 1$ at $12 \mathrm{~h}$. Then, endotoxin of $S$. Typhi promoted differential expression profile of TGF- $\beta$ s and their receptors in a time-dependent manner. The addition of $S$. Typhi. LPS to the cell cultures was manifested by higher transcriptional activity of TGF- $\beta 2,-\beta 3, \mathrm{~T} \beta \mathrm{RI}$, and $\mathrm{T} \beta \mathrm{RII}$ at $3 \mathrm{~h}$, but longer stimulation of Caco- 2 resulted in up-regulation of TGF- $\beta 1$ and all receptors. IP6 had no effect on LPS-altered expression of TGF- $\beta 1$. However, it enhanced LPS-increased mRNA expression of TGF- $\beta 2$ and $-\beta 3$. Likewise, this agent was capable of activating LPS-downregulated transcription of $\mathrm{T} \beta \mathrm{RI}, \mathrm{II}$ and III after $12 \mathrm{~h}$. 
According to the published data, the proinflammatory cytokines like IL-1, TNF- $\alpha$, and IFN- $\gamma$ increased the production of TGF- $\beta$ isoforms [44]. The main source of IL-1 in IBD patients is the monocyte/macrophage system and active IL- $1 \beta$ is released into the colonic mucosa [45]. Low concentrations of IL-1 $\beta$ have been shown to induce local inflammatory response followed by the activation of protective immune response [46].

As shown in this study, IL-1 $\beta$ stimulation of the epithelial cells up-regulated mRNA levels of all TGF- $\beta$ isoforms and their receptors at both $3 \mathrm{~h}$ and $12 \mathrm{~h}$. IP6 counteracted the stimulatory effect of IL- $1 \beta$ on TGF- $\beta 1, T \beta R I I$, and T $\beta$ RIII genes expression in Caco- 2 cells by decreasing their mRNA levels in $12 \mathrm{~h}$ lasting cultures. Furthermore, IP6 acted synergistically with IL- $1 \beta$ by enhancing the transcription of TGF- $\beta 2$ and $-\beta 3$ isoforms at $3 \mathrm{~h}$.

TGB- $\beta$ s exert their effects via activation of heteromeric receptor complexes of T $\beta$ RI and T $\beta$ RII. They can also interact with the type III receptor. This receptor acts as an enhancer of TGF- $\beta$ s activities by promoting their access to the signaling receptors, especially that of TGF- $\beta 2$ isoform which has a low affinity for the type II receptor [47]. The differential impact of IP6 on the expression of mRNA TGF- $\beta$ s and their receptors in colon epithelium under inflammatory conditions may be related to the role which these isoforms play. The three isoforms of TGF- $\beta$ are distributed in specific spatial and temporal patterns in the tissues and demonstrate distinct biological activities. The TGF- $\beta 2$ and $-\beta 3$ isoforms, whose expression was enhanced by IP6, are the effective inhibitors of epithelial proliferation. TGF- $\beta 3$ may be most effective in inducing epithelial wound repair [48]. TGF- $\beta 2$ suppresses IFN- $\gamma$ and IL- 1 at the transcriptional level and plays a critical role in the development of tolerance and the prevention of autoimmunity and anti-inflammatory responses [49]. Also, the increased expression of TGF- $\beta 1$ mRNA in Caco- 2 cells treated with IP6 for $3 \mathrm{~h}$ following E. coli endotoxin pretreatment may indicate its anti-inflammatory activity in relation to this LPS. A variety of pathogenic and proinflammatory stimuli upregulate SMAD7 mRNA expression, which in turn suppresses the TGF- $\beta$ pathway, through activation of NF$\kappa \mathrm{B}$. Bitzer et al. [13] show that p65/RelA subunit of NF$\kappa \mathrm{B}$ is required for transcriptional activation of SMAD7 by bacterial LPS and the proinflammatory cytokines (IL-1 $\beta$, TNF- $\alpha$ ). Inositol hexaphosphate exerts influence on cells via phosphatidylinositol-3 kinase (PI3K), MAPK, PKC, AP-1, and NF- $\kappa \mathrm{B}[28,29]$. Our previously published data demonstrated that IP6 modulated the expression of p65 subunit of nuclear factor $\kappa \mathrm{B}$ and its $\mathrm{I} \kappa \mathrm{B} \alpha$ inhibitor in the intestinal epithelial cells [31].

Diseases characterized by chronic inflammation frequently result in irreversible organ dysfunction due to extensive tissue fibrosis. Intestinal fibrosis is often a part of the natural course of IBD. TGF- $\beta$, in particular the TGF- $\beta 1$ isoform, is a potent profibrogenic agent inducing collagen synthesis and regulating the balance between matrix-degrading metalloproteinases (MMPs) and their inhibitors (TIMPs) [50]. According to Hong et al. [5], natural or synthesized agents that suppress and blockade TGF- $\beta$ signaling generally demonstrate anti-inflammatory and anti-fibrotic activities.
Rahal et al. [51] underline that, there are no IBD therapies that have been shown to specifically decrease fibrosis. They investigated the ability of resveratrol, a naturally occurring phytochemical, to decrease inflammation and fibrosis in an animal model of $\mathrm{CD}$ and showed the reduction of inflammatory cytokines as a promising trend in decreasing tissue fibrosis. The results of the present study demonstrate that IP6 is able to significantly downregulate TGF- $\beta 1, T \beta R I$, and T $\beta$ RIII activities in colon epithelial cells stimulated with proinflammatory agents IL-1 $\beta$ and E. coli LPS. Moreover, in the recently published studies, we reported that IP6 influenced constitutive expression of both MMP and TIMP genes and downregulated IL-1 $\beta$-stimulated transcription of some of these genes in the intestinal epithelial cells [52]. Taken together, we postulate that IP6 can attenuate inflammation and fibrosis in intestinal epithelium. Our results were consistent with the report of Kamp et al., [53] who concluded that IP6 reduced pulmonary inflammation and fibrosis in the respiratory bronchioles of rats.

In summary, the present findings suggest that IP6 can suppress the inflammation and exert chemopreventive activity through the modulation of expression of genes encoding TGF- $\beta$ s and their receptors. The current data confirm our previous conclusions that IP6 present in the intestinal milieu may exert immunoregulatory effects on colonic epithelium under inflammatory conditions or during microbe-induced infection/inflammation in order to maintain the colonic mucosa in a noninflammatory state or to counteract infection $[35,37]$. Inositol hexaphosphate with its anti-inflammatory and antifibrotic properties seems to be an ideal drug candidate to adjunct therapy of IBD and inflammation-associated colon cancer. Therefore, it is tempting to hypothesize that supplementing the diet of IP6 could be beneficial for preventing or reducing the inflammatory reactions and fibrosis in the intestine.

\section{Conflict of Interests}

The authors report no conflict of interests related to this study or the findings specified in this paper.

\section{Acknowledgment}

This work was supported by Grant no. KNW-1-048/k/3/0 from the Medical University of Silesia (Katowice, Poland).

\section{References}

[1] D. C. Baumgart and S. R. Carding, "Inflammatory bowel disease: cause and immunobiology," The Lancet, vol. 369, no. 9573, pp. 1627-1640, 2007.

[2] U. Böcker, O. Yezerskyy, P. Feick et al., "Responsiveness of intestinal epithelial cell lines to lipopolysaccharide is correlated with Toll-like receptor 4 but not Toll-like receptor 2 or CD14 expression," International Journal of Colorectal Disease, vol. 18, no. 1, pp. 25-32, 2003.

[3] R. M. Al-Sadi and T. Y. Ma, "IL-1 $\beta$ causes an increase in intestinal epithelial tight junction permeability," Journal of Immunology, vol. 178, no. 7, pp. 4641-4649, 2007. 
[4] M. Ligumsky, P. L. Simon, F. Karmeli et al., "Role of interleukin 1 in inflammatory bowel disease-enhanced production during active disease," Gut, vol. 31, no. 6, pp. 686-689, 1990.

[5] S. Hong, H.-J. Lee, S. J. Kim, and K.-B. Hahm, "Connection between inflammation and carcinogenesis in gastrointestinal tract: focus on TGF- $\beta$ signaling," World Journal of Gastroenterology, vol. 16, no. 17, pp. 2080-2093, 2010.

[6] R. L. Elliott and G. C. Blobe, "Role of transforming growth factor beta in human cancer," Journal of Clinical Oncology, vol. 23, no. 9, pp. 2078-2093, 2005.

[7] B. Bierie and H. L. Moses, "Transforming growth factor beta (TGF- $\beta$ ) and inflammation in cancer," Cytokine and Growth Factor Reviews, vol. 21, no. 1, pp. 49-59, 2010.

[8] R. Paduch and P. Niedziela, "TGF-betal influence on TNFalpha production and sTNF-Rs shedding in a coculture of colon carcinoma cell spheroids with normal cells," In Vitro Cellular and Developmental Biology, vol. 45, no. 7, pp. 371-377, 2009.

[9] L. Yang, Y. Pang, and H. L. Moses, “TGF- $\beta$ and immune cells: an important regulatory axis in the tumor microenvironment and progression," Trends in Immunology, vol. 31, no. 6, pp. 220-227, 2010.

[10] L. Kubiczkova, L. Sedlarikova, R. Hajek et al., “TGF- $\beta$-an excellent servant but a bad master," Journal of Translational Medicine, vol. 10, pp. 183-207, 2012.

[11] C.-H. Heldin, K. Miyazono, and P. Ten Dijke, “TGF- $\beta$ signalling from cell membrane to nucleus through SMAD proteins," Nature, vol. 390, no. 6659, pp. 465-471, 1997.

[12] A. Moustakas and C.-H. Heldin, "The regulation of TGF $\beta$ signal transduction," Development, vol. 136, no. 22, pp. 3699-3714, 2009.

[13] M. Bitzer, G. von Gersdorff, D. Liang et al., "A mechanism of suppression of TGF- $\beta /$ SMAD signaling by NF- $\kappa \mathrm{B} /$ RelA," Genes and Development, vol. 14, no. 2, pp. 187-197, 2000.

[14] A. Rizzo, M. J. Waldner, C. Stolfi et al., "Smad7 expression in T cells prevents colitis-associated cancer," Cancer Research, vol. 71, no. 24, pp. 7423-7432, 2011.

[15] J. Massague, "TGF $\beta$ signalling in context," Nature Reviews Molecular Cell Biology, vol. 13, no. 10, pp. 616-630, 2012.

[16] M. W. Saif and E. Chu, "Biology of colorectal cancer," Cancer Journal, vol. 16, no. 3, pp. 196-201, 2010.

[17] K.-B. Hahm, Y.-H. Im, T. W. Parks et al., "Loss of transforming growth factor $\beta$ signalling in the intestine contributes to tissue injury in inflammatory bowel disease," Gut, vol. 49, no. 2, pp. 190-198, 2001.

[18] J. F. S. Santibañez, M. Quintanilla, and C. Bernabeu, "TGF$\beta /$ TGF- $\beta$ receptor system and its role in physiological and pathological conditions," Clinical Science, vol. 121, no. 6, pp. 233251, 2011.

[19] G. Monteleone, A. Kumberova, N. M. Croft, C. McKenzie, H. W. Steer, and T. T. MacDonald, "Blocking Smad7 restores TGF- $\beta 1$ signaling in chronic inflammatory bowel disease," The Journal of Clinical Investigation, vol. 108, no. 4, pp. 601-609, 2001.

[20] G. Monteleone, R. Caruso, and F. Pallone, "Role of Smad7 in inflammatory bowel diseases," World Journal of Gastroenterology, vol. 18, no. 40, pp. 5664-5668, 2012.

[21] S. P. Hussain and C. C. Harris, "Inflammation and cancer: an ancient link with novel potentials," International Journal of Cancer, vol. 121, no. 11, pp. 2373-2380, 2007.

[22] H. Lu, W. Ouyang, and C. Huang, "Inflammation, a key event in cancer development," Molecular Cancer Research, vol. 4, no. 4, pp. 221-233, 2006.
[23] J. Ferlay, H.-R. Shin, F. Bray, D. Forman, C. Mathers, and D. M. Parkin, "Estimates of worldwide burden of cancer in 2008: GLOBOCAN 2008," International Journal of Cancer, vol. 127, no. 12, pp. 2893-2917, 2010.

[24] B. Rousseau, B. Chibaudel, J.-B. Bachet et al., "Stage II and stage III colon cancer: treatment advances and future directions," Cancer Journal, vol. 16, no. 3, pp. 202-209, 2010.

[25] P. A. Thompson and E. W. Gerner, "Current concepts in colorectal cancer prevention," Expert Review of Gastroenterology and Hepatology, vol. 3, no. 4, pp. 369-382, 2009.

[26] I. Vucenik and A. M. Shamsuddin, "Protection against cancer by dietary IP6 and inositol," Nutrition and Cancer, vol. 55, no. 2, pp. 109-125, 2006.

[27] M. Gu, K. Raina, C. Agarwal, and R. Agarwal, "Inositol hexaphosphate downregulates both constitutive and ligandinduced mitogenic and cell survival signaling, and causes caspase-mediated apoptotic death of human prostate carcinoma PC-3 cells," Molecular Carcinogenesis, vol. 49, no. 1, pp. 1-12, 2010.

[28] A. Matejuk and A. Shamsuddin, "IP6 in cancer therapy: past, present and future," Current Cancer Therapy Reviews, vol. 6, no. 1, pp. 1-12, 2010.

[29] J. Liao, D. N. Seril, A. L. Yang, G. G. Lu, and G.-Y. Yang, "Inhibition of chronic ulcerative colitis associated adenocarcinoma development in mice by inositol compounds," Carcinogenesis, vol. 28, no. 2, pp. 446-454, 2007.

[30] M. Kapral, J. Wawszczyk, A. Hollek et al., "Induction of the expression of genes encoding TGF- $\beta$, isoforms and their receptors by inositol hexaphosphate in human colon cancer cells," Acta Poloniae Pharmaceutica, vol. 70, no. 2, pp. 357-363, 2013.

[31] M. Kapral, B. Parfiniewicz, B. Strzałka-Mrozik, A. Zachacz, and L. Węglarz, "Evaluation of the expression of transcriptional factor NF- $\kappa \mathrm{B}$ induced by phytic acid in colon cancer cells," Acta Poloniae Pharmaceutica, vol. 65, no. 6, pp. 697-702, 2008.

[32] Y. S. Kim, M. R. Young, G. Bobe, N. H. Colburn, and J. A. Milner, "Bioactive food components, inflammatory targets, and cancer prevention," Cancer Prevention Research, vol. 2, no. 3, pp. 200208, 2009.

[33] C. D. Davis, "Nutritional interactions: credentialing of molecular targets for cancer prevention," Experimental Biology and Medicine, vol. 232, no. 2, pp. 176-183, 2007.

[34] J.-M. Cherng, W. Chiang, and L.-C. Chiang, "Immunomodulatory activities of edible beans and related constituents from soybean," Food Chemistry, vol. 104, no. 2, pp. 613-618, 2007.

[35] L. Wȩglarz, J. Wawszczyk, A. Orchel, M. Jaworska-Kik, and Z. Dzierzewicz, "Phytic acid modulates in vitro IL-8 and IL-6 release from colonic epithelial cells stimulated with LPS and IL1 $\beta$,' Digestive Diseases and Sciences, vol. 52, no. 1, pp. 93-102, 2007.

[36] K. Cholewa, B. Parfiniewicz, I. Bednarek et al., "The influence of phytic acid on TNF- $\alpha$ and its receptors genes' expression in colon cancer Caco-2 cells," Acta Poloniae Pharmaceutica, vol. 65, no. 1, pp. 75-79, 2008.

[37] J. Wawszczyk, M. Kapral, A. Hollek et al., "The effect of phytic acid on the expression of NF- $\kappa$ B, IL- 6 and IL- 8 in IL$1 \beta$-stimulated human colonic epithelial cells," Acta Poloniae Pharmaceutica, vol. 69, no. 6, pp. 1313-1319, 2012.

[38] L. H. Zeuthen, L. N. Fink, and H. Frokiaer, "Epithelial cells prime the immune response to an array of gut-derived commensals towards a tolerogenic phenotype through distinct 
actions of thymic stromal lymphopoietin and transforming growth factor- $\beta$," Immunology, vol. 123, no. 2, pp. 197-208, 2008.

[39] D. Haller, C. Bode, W. P. Hammes, A. M. A. Pfeifer, E. J. Schiffrin, and S. Blum, "Non-pathogenic bacteria elicit a differential cytokine response by intestinal epithelial cell/leucocyte co-cultures," Gut, vol. 47, no. 1, pp. 79-87, 2000.

[40] T. Yoshioka, Y. Morimoto, H. Iwagaki et al., "Bacterial lipopolysaccharide induces transforming growth factor $\beta$ and hepatocyte growth factor through toll-like receptor 2 in cultured human colon cancer cells," Journal of International Medical Research, vol. 29, no. 5, pp. 409-420, 2001.

[41] J. van de Walle, A. Hendrickx, B. Romier, Y. Larondelle, and Y.-J. Schneider, "Inflammatory parameters in Caco-2 cells: effect of stimuli nature, concentration, combination and cell differentiation," Toxicology in Vitro, vol. 24, no. 5, pp. 1441-1449, 2010.

[42] M. Rossol, H. Heine, U. Meusch et al., "LPS-induced cytokine production in human monocytes and macrophages," Critical Reviews in Immunology, vol. 31, no. 5, pp. 379-446, 2011.

[43] B. Bahrami, S. Macfarlane, and G. T. Macfarlane, "Induction of cytokine formation by human intestinal bacteria in gut epithelial cell lines," Journal of Applied Microbiology, vol. 110, no. 1, pp. 353-363, 2011.

[44] I. Drygiannakis, V. Valatas, O. Sfakianaki et al., "Proinflammatory cytokines induce crosstalk between colonic epithelial cells and subepithelial myofibroblasts: implication in intestinal fibrosis," Journal of Crohn's and Colitis, vol. 7, no. 4, pp. 286-300, 2013.

[45] M. E. McAlindon, C. J. Hawkey, and Y. R. Mahida, "Expression of interleukin $1 \beta$ and interleukin $1 \beta$ converting enzyme by intestinal macrophages in health and inflammatory bowel disease," Gut, vol. 42, no. 2, pp. 214-219, 1998.

[46] R. N. Apte and E. Voronov, "Interleukin-1 - major pleiotropic cytokine in tumor-host interactions," Seminars in Cancer Biology, vol. 12, no. 4, pp. 277-290, 2002.

[47] G. de Crescenzo, S. Grothe, J. Zwaagstra, M. Tsang, and M. D. O'Connor-McCourt, "Real-time monitoring of the interactions of transforming growth factor- $\beta$ (TGF- $\beta$ ) isoforms with latency-associated protein and the ectodomains of the TGF- $\beta$ type II and III receptors reveals different kinetic models and stoichiometries of binding," The Journal of Biological Chemistry, vol. 276, no. 32, pp. 29632-29643, 2001.

[48] B. C. Mckaig, K. Hughes, P. J. Tighe, and A. Y. R. Mahida, "Differential expression of TGF- $\beta$ isoforms by normal and inflammatory bowel disease intestinal myofibroblasts," American Journal of Physiology: Cell Physiology, vol. 282, no. 1, pp. C172-C182, 2002.

[49] Y.-J. Lee, Y. Han, H.-T. Lu et al., “TGF- $\beta$ suppresses IFN$\gamma$ induction of class II MHC gene expression by inhibiting class II transactivator messenger RNA expression," Journal of Immunology, vol. 158, no. 5, pp. 2065-2075, 1997.

[50] A. Di Sabatino, C. L. Jackson, K. M. Pickard et al., "Transforming growth factor $\beta$ signalling and matrix metalloproteinases in the mucosa overlying Crohn's disease strictures," Gut, vol. 58, no. 6, pp. 777-789, 2009.

[51] K. Rahal, P. Schmiedlin-Ren, J. Adler et al., "Resveratrol has antiinflammatory and antifibrotic effects in the peptidoglycanpolysaccharide rat model of Crohn's disease," Inflammatory Bowel Diseases, vol. 18, no. 4, pp. 613-623, 2012.

[52] M. Kapral, J. Wawszczyk, M. Jurzak, A. Hollek, and L. Weglarz, "The effect of inositol hexaphosphate on the expression of selected metalloproteinases and their tissue inhibitors in IL- $1 \beta$ stimulated colon cancer cells," International Journal of Colorectal Disease, vol. 27, no. 11, pp. 1419-1428, 2012.

[53] D. W. Kamp, V. A. Israbian, A. V. Yeldandi, R. J. Panos, P. Graceffa, and S. A. Weitzman, "Phytic acid, an iron chelator, attenuates pulmonary inflammation and fibrosis in rats after intratracheal instillation of asbestos," Toxicologic Pathology, vol. 23, no. 6, pp. 689-695, 1995. 


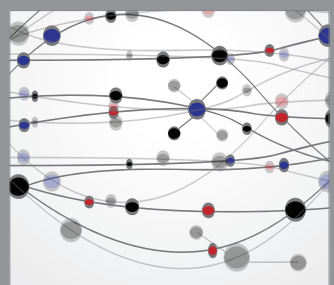

The Scientific World Journal
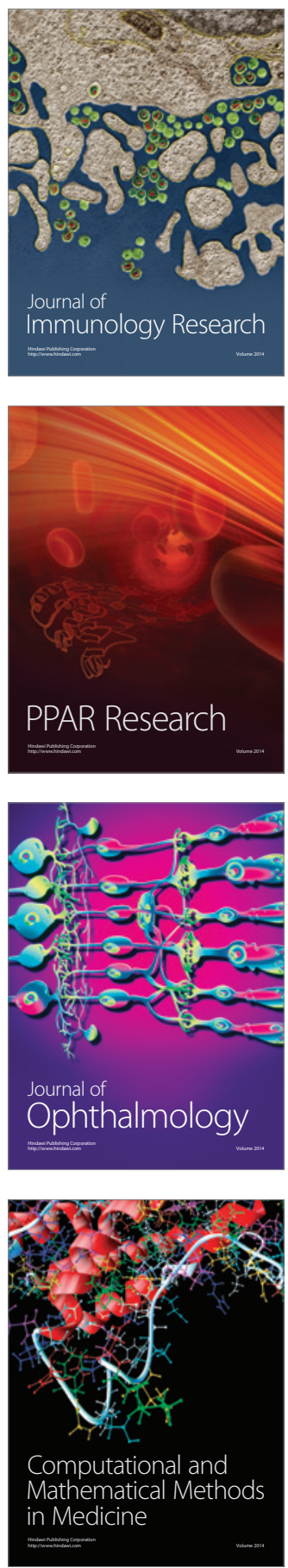

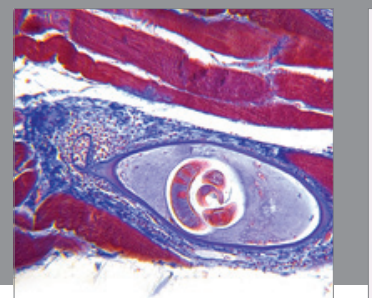

Gastroenterology

Research and Practice
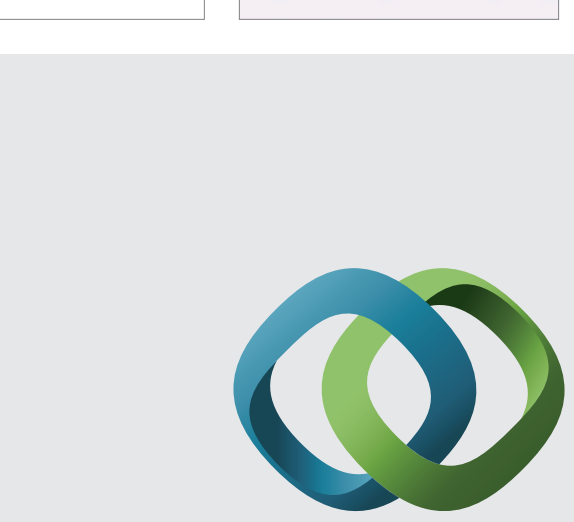

\section{Hindawi}

Submit your manuscripts at

http://www.hindawi.com
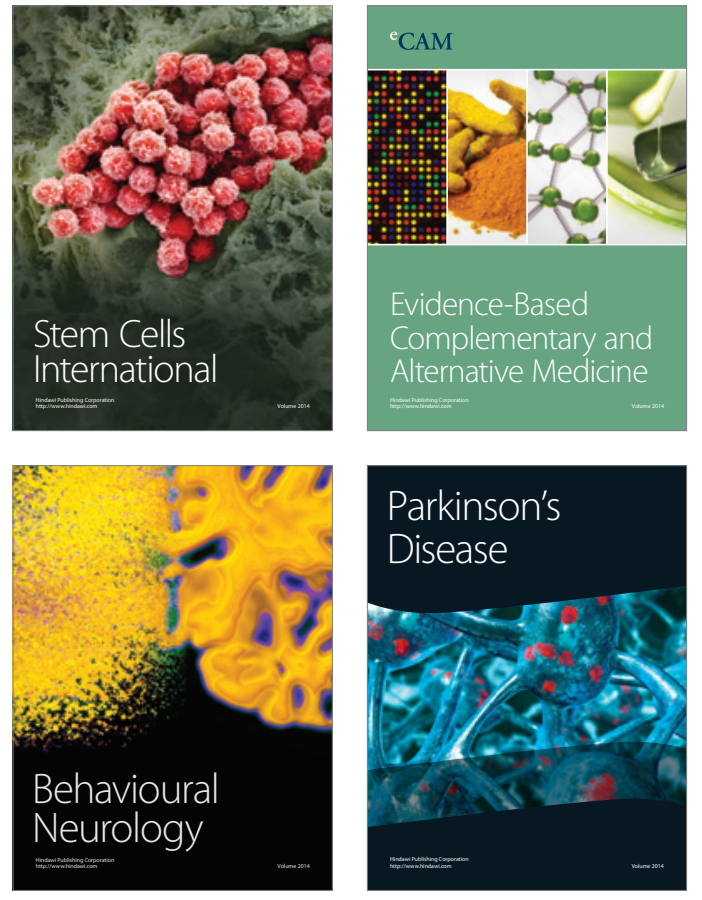
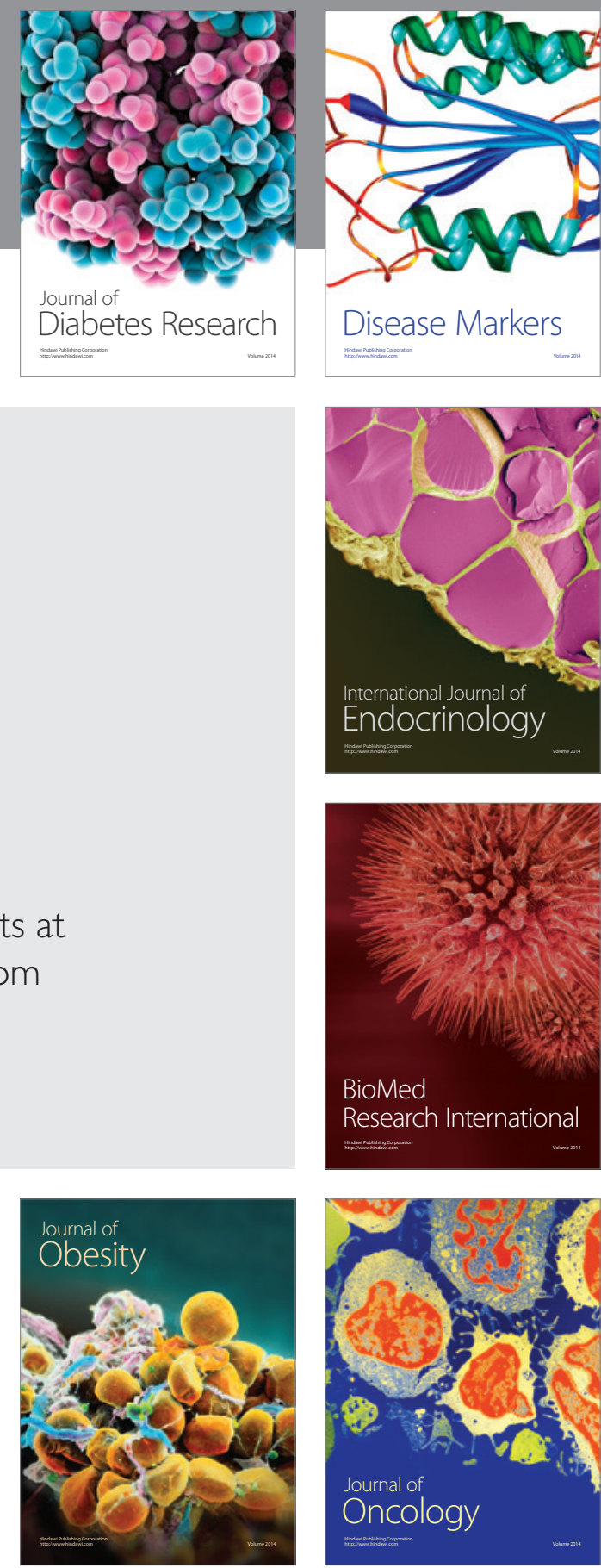

Disease Markers
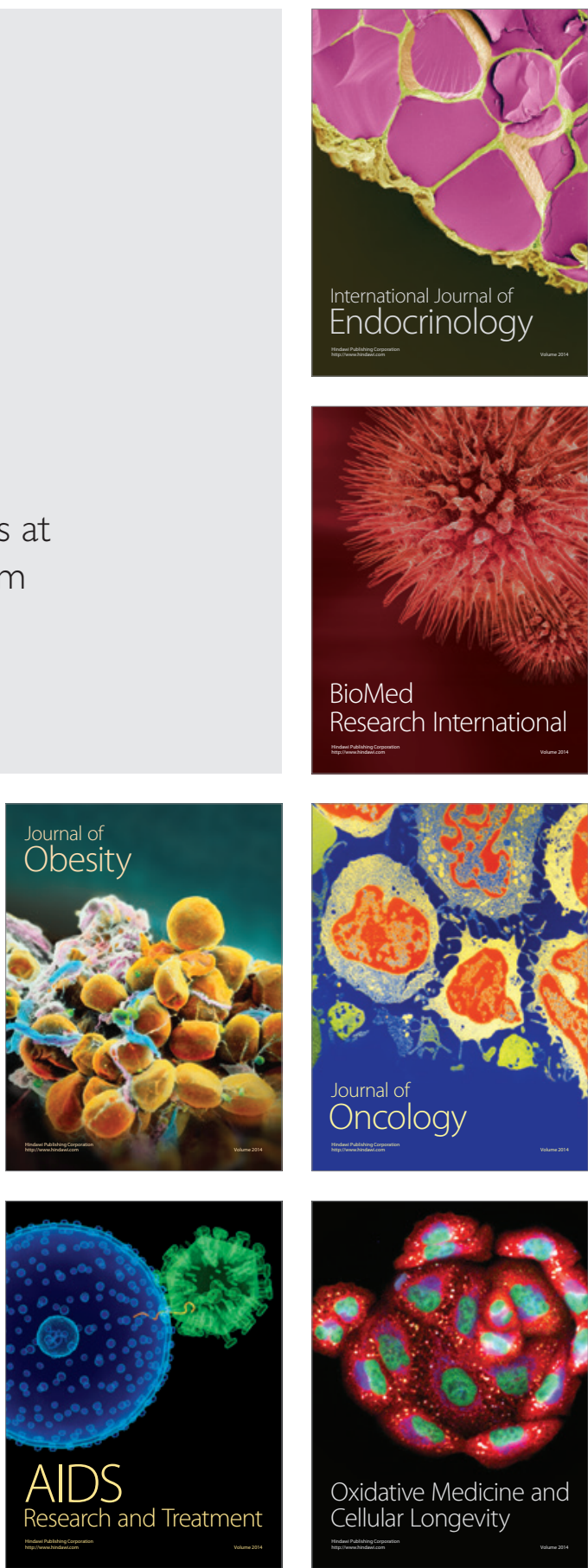